\title{
Pedagogical Conditions of Development of Social Worker Communication Culture in Post-Qualifying Training
}

\author{
Galyna Miasoid \\ Associate Professor \\ The Department of International Tourism and Language Training \\ Alfred Nobel University \\ Naberezhna Lenina str., 18, Dnipropetrovsk, Ukraine - 49055 \\ Corresponding Email: galyna.miasoid@gmail.com
}

\begin{abstract}
Keywords: social work, communication culture, social worker communication culture, motivationalvalue component, behavioural component, professional ethic qualities, motivations, values, communication skills, interaction skills, perception skills.
\end{abstract}

\begin{abstract}
The paper addresses the problem of underdeveloped communication culture of social workers in Ukraine. The term of 'social worker communicative culture' has been defined and its components have been listed. The criteria, parameters and development levels of social worker communication culture have been examined. Summative assessment has shown through the combination of quantitative and qualitative data analyses that communication culture of social workers in Ukraine should be resolved urgently. The pedagogical conditions of social worker communication culture development and the suggested methodology have been substantiated and verified in a post-qualifying training. The obtained results can be of help when designing the training programmes for social workers in the Social Welfare System in Ukraine and other developing countries undergoing social and economic reforms.
\end{abstract}

\section{Introduction}

Social work as a professional practice has a long history around the world though it is still a relatively new practice for Ukraine. The recent studies and best practices of social work and vocational training for social work underscore the integration of practice and research, practice and training. They are the sources of methodologies and criteria, as well as benchmarks for assessing the skills students and practitioners acquire through training programmes. The previous research also serves as a valuable source of the learning objectives of the future Ukraine still has to enter, as countries with a longer history of social work share their experiences.

One of the most important issues of vocational training for social work is competences or standards of proficiency [1,2]. Thus, Standards of proficiency of social workers in England [2] focuses on a range of skills which refer to social workers ability to communicate effectively and interact appropriately with other people and follow the ethics of social work. It is clear that both educational establishments and social work centres aim at ensuring the values and practice of social work. The close relationship between social life, performance and communication skills has been investigated by many researchers. Morreale, Osborn \& Pearson (2000) examined the impact of communication education for the development of a person and found that it improves critical thinking as well as cements relationships to the self, others, and society and is generally of high value as it affects shaping social our life [3]. This view of communication meets the requirements to the core competences of social work underpinned in the educational policy and accreditation standards of CSWE (2008). Seeking to improve communication between social inspectors and customers of Social Welfare System of Ukraine, Miasoid (2003) studies communication channels used by social inspectors to perform their mission and the structure of communicative culture of social workers. Also the researcher worked out the questioners for both self-assessment used as research tools in the present study [4]. According to those findings, the communicative culture of a social worker comprises interrelated components, namely the motivational-value component and the behavioural component. Moreover, the Core competencies and practice behaviours [5] listed in 
Educational Policy and Accreditation Standards (EPAS) were used as criteria for expert assessment of the behavioural component while core values of CSWE (2008) and the corresponding practices served for elaborating the self-assessment research tool needed for the current study. To ensure the valid assessment of the ethical values that are essential for making ethical decisions in any of the situations a social worker might need to do the job and which are the elements of the motivationalvalue component of the communicative culture, we designed a questionnaire that also reflects the Codes of Ethics of Social Work of national associations of social workers $[6,7,8]$.

The specific features of professional interaction of social inspectors were thoroughly examined by Miasoid (2005) in her previous research [9]. The social inspectors are responsible for assessing the income level of individuals or families applying for single-purpose targeted aid from the state and are the part of the Social Welfare System of Ukraine. Specific pedagogical conditions to help social workers develop their communication culture in post-qualifying training substantiated in the paper [9] were used as the basis to work out the effective forms and teaching materials to train social workers during the current study. However, further research was needed to solve a problem of insufficient training social workers in Ukraine have nowadays because many of them a new to this profession and the system lacks in qualified practitioners. For this purpose, A G20 Training Strategy [10] was considered which focused on the necessity to provide lifelong learning for lifelong employability of workers in all fields which is applicable to updating qualification of social workers. Furthermore, the benchmarks for assessing the learning objectives in social work [11] elaborated by the Department of Social Work of University of Alaska Fairbanks present useful criteria for the learning outcomes assessment.

Using the mentioned approaches and studies, the present paper seeks to examine the level of communication culture of unexperienced social workers in Ukraine, and provide an effective training course for them in the skill-upgrading training within the Social Welfare System of Ukraine.

\section{Methodology}

The research was conducted through the 2014-2015 academic year on the base of the System of Work and Welfare in Dnipropetrovsk and Zaporizhzhya regions. It involved 384 social workers and 6 experts at both the summative and formative assessment stages of the research.

The research object is development of social inspector communicative culture.

The research subject is pedagogical conditions of social inspector communicative culture development in the system of post-graduate training.

The study aimed at substantiating and experimental validation of pedagogical conditions of social inspector communicative culture development in the system of post-qualifying training.

To achieve the research objective we have completed the tasks listed below:

1. Defined the term of 'social worker communication culture' having analysed the main approaches to communicative culture development and found ways to improve it.

2. Listed and examined the criteria, parameters and development levels of social worker communication culture.

3. Substantiated pedagogical conditions of social worker communication culture development which help to effectively form its structural elements and acquire skills of professional communication.

4. Worked out the methodology of social worker communication culture development that ensures implementation of the substantiated pedagogical conditions, and experimentally validated this methodology in social inspector post-qualifying training.

Research Design and Details. The research base: the System of Work and Welfare of Ukraine in Dnipropetrovsk and Zaporizhzhya regions. The research involved 384 social workers and 6 experts at both the summative and formative assessment stages of the research.

Summative stage. The research methods: previous research analysis, content analysis, survey, qualitative and quantitative analysis.

Representative sample: 254 social workers and social inspectors. 
Formative stage. The research methods: pedagogical experiment, survey (self-assessment, expert assessment), statistic analysis, qualitative and quantitative analysis.

Representative sample: Experimental and control groups (65 social inspectors each) a 21 hour course "Social Worker Professional Communication."

Forms and Methods of Teaching and Learning: social psychological training, group and pair research, mini-lectures, discussions, situation analysis, role play, simulation, training, professional communication try-storming, exercise, assignments, feedback.

During the summative assessment, we used the research tools for self- and expert assessment used in our previous research. To examine the structure of social inspector communicative culture we analysed research reports, communication channels of the Social Welfare System of Ukraine, and requirements to customer service in the field.To ensure the validity of the obtained data to requirements to social work around the world, the Core competencies and practice behaviours (2015) listed in Educational Policy and Accreditation Standards (EPAS) were used as criteria for expert assessment of the behavioural component while core values of CSWE (2008) and the corresponding practices served for elaborating the self-assessment research tool needed for the current study.

We used a diagnostic technique to differentiate between the levels of communicative culture social workers have. We analysed the extent to which the elements within the two of its components, namely of the motivational-value unit and the behavioural unit, were formed. The motivational-value component was classified by information-cognitive and motivation-value tests. The behavioural component was classified by operational-activity test (Miasoid, 2005).

These criteria have such test parameters:

1. The information-cognitive test parameters are professional ethic qualities and realization of own communicative culture level.

2. The motivation-value test parameters are values and motivations.

3. The operational-activity test parameters are communication, interaction and perception skills.

From the obtained results it is apparent that social inspectors view the perception skills as the most significant tool to build effective communication, though they are not enough acquired. The least acquired are communication skills of social inspectors.

\section{Results and Discussion}

Summative assessment. The research is relevant as, on the one hand, there is high demand for social workers skilful in professional communication to carry out professional communicative activities that a social inspector is responsible for and, on the other hand, there is a lack of research on the development of their communicative culture during vocational post-graduate training in the System of Social Welfare in Ukraine.

To examine the structure of social inspector communicative culture we analysed research reports, communication channels of the Social Welfare System of Ukraine, and requirements to customer service in the field. The obtained results demonstrated that a social worker is involved in both external (outside the Social Welfare System of Ukraine) and internal communication channels in a range of relationships (see Fig.1.) The communication channels found to be used within the body are subject-subject role (professional) and personal ones which a social worker uses when they communicate with executives, colleagues and/or subordinates. Among the major external communication channels social workers use are those linking a social worker to customers of a Social Welfare Body of a representative of other social bodies which may be necessary for a social worker to perform their duties. These channels of communication require that a social worker sticks to a certain communication format caused by relationship types. Therefore, using external channels, a social worker does role or professional communication, whereas inside the system relations can vary from role to personal. 


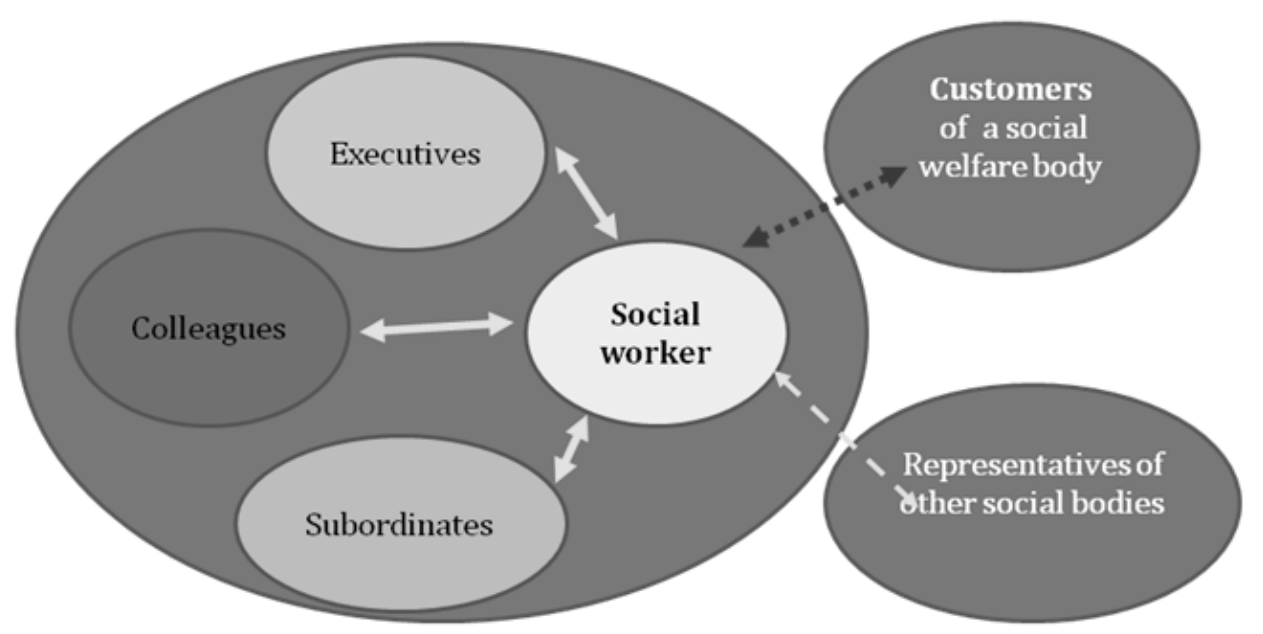

Fig.1. Communication Channels a Social Worker Uses in the Social Welfare System of Ukraine

\author{
Subject-subject relation type: \\ $\longleftrightarrow$ Role (professional) and personal communication \\ $\leftrightarrow$ Role (professional) communication
}

The previous research (Miasoid, 2005) clearly demonstrates that communication culture as a complex integral personal quality defined by the specific character of a person's professional activity, which includes motivational, axiological and behavioural components. These components are hierarchic mutually depended coherent systemic units which have subordinate elements, namely professionally important personal qualities, motivations and values as well as communication, interaction and perception skills.

Thus we view social worker communication culture as a part of communication culture that reflects the extent to which a social inspector acquired the base of knowledge in ethic norms, psychological principles and laws of communication, as well as communication skills and the way these norms and skills are relevant to personal values and motivations. The culture is demonstrated through behavioural patterns (see Fig. 2). As a result we found that communicative culture is a complex system with numerous elements and relations that form integrity. The components of the whole structure were relation-stratified.

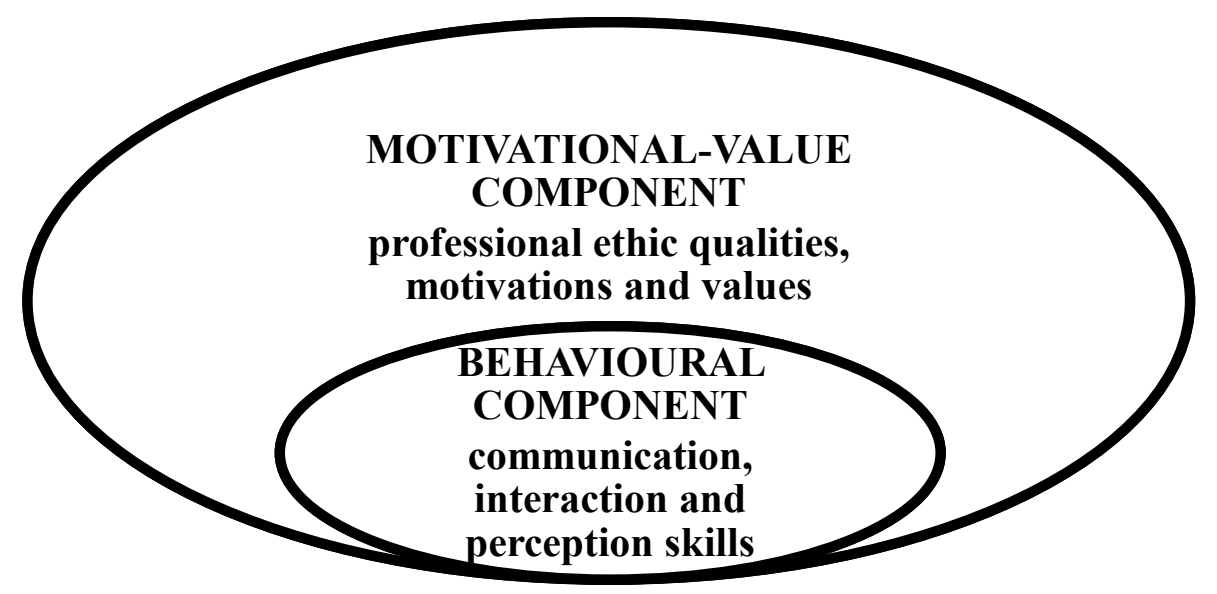

Fig.2. Hierarchy of mutually dependant elements and components of communicatione culture

From Fig. 2 we see, that a social worker chooses the way of achieving the communication objective according to own values, motivations and personal qualities, specified by professional activity. Therefore, behavioural patterns, i.e. communication tools and techniques to influence the collocutor clearly depend on a social inspector's values, motivations and professional ethic. 
During the summative assessment of social worker's professional operational status we found that from $43.4 \%$ till $49.6 \%$ of the respondents have different needs for development of problem solving and negotiation skills. Furthermore, their communication skills and abilities were examined. At this stage we revealed a range of deviations from a model before the pedagogic experiment was conducted. First, within the communication culture structure there was the imbalance of different components development levels. From the results we concluded that professional ethic qualities, motivations and values are on high level and make around $60 \%$ of the model, though communication, interaction and perception skills are at a low level and make around $30 \%$ of the model. At the same time, though job qualities are better developed when compared to the elements of the behavioural component, as social inspectors appeared to not to realize the effect communication has in their professional activity. We found that only a subject-object channel of sharing experience is used as a teaching method in social worker career development system. Moreover, both social workers and experts stress that qualification upgrading courses are the most efficient form of occupational upgrading, while methodical seminars still remain the most frequent form and it is ranked 3 in the list.

From the results of the summative assessment, we concluded that vocational training in social work in Ukraine does not aim at developing communication culture so that it meets the requirements of professional activity.

The study revealed that the existing system of vocational training in the field does not develop communication culture of social workers efficiently, though it is communication culture that enables them to build productive relationships with people involved in their work.

Among the weaknesses of vocational and post-qualifying training in Ukraine the four major points should be mentioned. They run as follows:

- The existing post-graduate training does not aim at developing people skills. It is mainly of an informative character aiming to get social workers acquainted with numerous changes in the legislation under reforms.

- It frequently employs a subject-object channel of sharing experience as a teaching method.

- The organisational form of learning that is most often chosen for such a training is a methodical seminar, which is a low-budget though the least effective one (as social workers in the survey point).

- As the survey has demonstrated, the special syllabus and instructional material for forming communication culture of social workers are urgently required.

Therefore, there is a need to substantiate pedagogical conditions of social worker communication culture development in the system of post-graduate training.

Methods of Teaching and Learning. The research findings regarding approaches to communicative culture and its elements development brought us to conclusion that a range of teaching methods can help to form its components. These methods are discussion, lecture, situation analysis, role play, simulation, training, professional communication try-storming, exercise, team work and group work.

We investigated the previous research on andragogy and personal culture development as well as didactic opportunities of context and interactive learning, and social-psychological training. This resulted in the model of social worker communication culture development. The model suggests a step-by-step acquisition of socio-psychological knowledge, professional ethics, values, motivations and skills reflected by social workers.

Social requirements to social worker professional skill arise from the specific character of their professional activity and job analysis which defines their social model. They confirm that there is a need for special syllabus and instructional material, which can help to form a body of knowledge, motivations, commitment and skills.

Summative assessment proved that the research is relevant and made it possible to define areas for improvement. They are methods of teaching and learning that provide a step by step development of social worker communication culture in the system of professional upgrading. 
Based on the research conducted, we substantiated the pedagogical conditions of social worker communication culture development in the system of professional upgrading. They define forms of learning interaction and instructional content.

The pedagogical conditions of social inspector communicative culture development should:

1) Provide development of communicative culture structural component development (motivation-value and behavioural) as integral systemic units that have mutually dependent hierarchy;

2) Form social inspectors' reflection on every component and element of own communicative culture;

3) Use the module approach to instructional material organisation, so that the course units reflect the specific features of social inspector professional communication;

4) Organise learning in groups on the principles of social psychological training, namely activity, initiative, sticking to team rules, mutual support, "here and now"

These conditions are relevant, and only a set of them can help achieve the objective to develop communication culture. We verified these conditions through the relevant methodology during the formative assessment stage of the research.

The methodology was based on the "Social worker professional communication" course (see Table 1), which includes seven units (modules) reflecting the communicative training of social inspectors in the professional upgrading system.

Table 1. The "Social Worker Professional Communication" Course Plan

\begin{tabular}{|c|l|c|c|}
\hline \multicolumn{1}{|c|}{ Module theme } & $\begin{array}{c}\text { Contact } \\
\text { hours }\end{array}$ & Classes \\
\hline 1. & Communication in the Social Welfare System of Ukraine & 3 & 2 \\
\hline 1.1. & Course presentation & 1.5 & 1 \\
\hline 1.2. & Social worker communicative culture. Social worker ethics. & 1.5 & 1 \\
\hline 2. & Social worker speaking skills & 4.5 & 3 \\
\hline 2.1. & Qualities and skills important for communication & 1.5 & 1 \\
\hline 2.2. & Presentation, self-presentation, communication styles & 3 & 2 \\
\hline 3. & Conversation and its specific characteristics & 4.5 & 3 \\
\hline 3.1. & Conversation role in the social worker professional activity & 1.5 & 1 \\
\hline 3.2. & Communication barriers & 1.5 & 1 \\
\hline 3.3. & $\begin{array}{l}\text { Dealing with negative reactions and negative qualities of a } \\
\text { collocutor }\end{array}$ & 1.5 & 1 \\
\hline 4. & Teamwork. Leadership issues & 1.5 & 1 \\
\hline 5. & Conflict: what is it and how to deal with it? & 3 & 2 \\
\hline 6. & Direct contacts and aided/mediated communication & 3 & 2 \\
\hline 6.1. & Active listening & 1.5 & 1 \\
\hline 6.2. & Telephone communication and a social worker. & 1.5 & 1 \\
\hline & Written communication. & 1.5 & 1 \\
\hline 7. & Generalizing class. & 21 & 14 \\
\hline
\end{tabular}

The main forms and tools of communication culture development used in the course were social psychological training, group and pair research, mini-lectures, discussions, situation analysis, exercise, role play, simulation, training, professional communication try-storming, exercise, as well as home assignments and feedback to help social workers form reflection on their communication.

We verified the efficiency of the course content, teaching and learning methods as well as organisation forms in achieving the course objectives through formative assessment. To do it we compared the results obtained in both experimental and control (screening) group the before and after the experimental training. The results thus obtained are provided in Table 2. 


\section{Table 2. Social Inspector Communication Culture Levels in Experimental and Screening Groups}

\begin{tabular}{|c|c|c|c|c|}
\hline $\begin{array}{c}\text { Levels of communicative } \\
\text { culture }\end{array}$ & \multicolumn{2}{|c|}{$\begin{array}{c}\text { Experimental } \\
\text { group } \\
\text { assessment } \\
(\mathrm{n}=65), \%\end{array}$} & \multicolumn{2}{c|}{$\begin{array}{c}\text { Screening } \\
\text { group } \\
\text { assessment } \\
(\mathrm{n}=65), \%\end{array}$} \\
\cline { 2 - 5 } & 1 test & 2 test & 1 test & 2 test \\
\hline High & 26.4 & 39.0 & 26.9 & 30.1 \\
\hline Medium & 48.4 & 44.0 & 47.9 & 46.7 \\
\hline Low & 25.2 & 17.0 & 25.2 & 23.2 \\
\hline
\end{tabular}

As seen from the data in Table 3, comparison of the first and second assessment results in the experimental group revealed the positive changes in such test parameters as self-analysis, selfassessment of own level of communicative culture, realization of communication role in work, and flexibility in the choice of communication style under various circumstances. We explain these changes by the reflexive character of the learning process. However, the test results in the $\mathrm{C}$ group do not differ under these parameters.

There were also the marked positive changes in the value formation in the experimental group. The biggest quantitative differences between the second assessment results in the two groups are in empathy, confidentiality, tolerance and honesty.

As for formation of job-related qualities both experimental and screening group showed insignificant differences, only two parameters differ in the experimental group, and one - in the $\mathrm{C}$ group. We explain this by the initially high rank of these qualities. The final results in such qualities as kindness, responsibility, humanity and creative thinking in both groups vary.

Table 3. Expert assessment of social worker communication culture development

\begin{tabular}{|c|c|c|c|c|c|c|c|c|c|c|c|c|}
\hline \multirow{4}{*}{ Elements } & \multicolumn{12}{|c|}{ Levels of component development } \\
\hline & \multicolumn{6}{|c|}{ Experimental group } & \multicolumn{6}{|c|}{ Screening group } \\
\hline & \multicolumn{2}{|c|}{ high } & \multicolumn{2}{|c|}{ medium } & \multicolumn{2}{|c|}{ low } & \multicolumn{2}{|c|}{ high } & \multicolumn{2}{|c|}{ medium } & \multicolumn{2}{|c|}{ low } \\
\hline & $\mathrm{I}$ & II & $\mathrm{I}$ & II & I & II & I & II & I & II & $\mathrm{I}$ & II \\
\hline $\begin{array}{l}\text { Realisation of own } \\
\text { communication } \\
\text { culture level }\end{array}$ & 8.9 & 19.8 & 34.7 & 32.6 & 21.4 & 12.6 & 8.4 & 9.2 & 35.9 & 35.8 & 20.7 & 20.0 \\
\hline Job qualities & 27.7 & 28.2 & 22.2 & 21.3 & 15.1 & 15.5 & 29.3 & 31.5 & 22.1 & 24.3 & 13.6 & 9.2 \\
\hline Values & 32.4 & 36.7 & 26.0 & 23.4 & 6.6 & 4.9 & 32.0 & 35.4 & 26.4 & 24.6 & 6.6 & 5.0 \\
\hline Motivations & 14.0 & 18.4 & 28.4 & 16.9 & 22.6 & 29.7 & 14.7 & 16.8 & 28.6 & 34.2 & 21.7 & 14.0 \\
\hline $\begin{array}{l}\text { Communication } \\
\text { skills }\end{array}$ & 9.3 & 25.9 & 35.3 & 34.4 & 20.4 & 4.7 & 8.7 & 11.2 & 34.5 & 33.7 & 21.8 & 20.1 \\
\hline Perception skills & 13.9 & 24.6 & 37.0 & 36.6 & 14.1 & 3.8 & 15.2 & 17.5 & 35.3 & 34.5 & 14.5 & 13.0 \\
\hline Interaction skills & 12.5 & 23.9 & 37.4 & 34.9 & 15.1 & 6.2 & 13.0 & 15.4 & 37.0 & 25.4 & 12.0 & 24.2 \\
\hline Integrated index & 16.9 & 25.4 & 31.5 & 28.6 & 16.8 & 11.1 & 17.3 & 19.6 & 31.4 & 30.4 & 15.8 & 15.1 \\
\hline Percentage & 26.1 & 39.0 & 48.5 & 44.0 & 25.8 & 17.0 & 26.7 & 30.1 & 48.3 & 46.7 & 24.4 & 23.2 \\
\hline
\end{tabular}

As seen from the data in Table 3, measured motivations in the second assessment show considerable variation from experimental group to the control one. Social workers in the experimental group demonstrated higher motivations for communication improvement in their work places, fulfilment, increase of own performance and job identification, self-training and staff morale, than social workers of the reference group. 
The operational-activity test parameters were applied to check the changes in skill acquisition in both experimental and $\mathrm{C}$ groups. Communication, interaction and perception skills developed significantly in the experimental group, whereas reference group demonstrated significant changes in a limited number of skills. This can be explained by recommendations on how to deal with customers suggested in the traditional post-graduate form of training. However, there were no apparent differences in behavioural component test parameters in the reference group.

To sum up, wide difference is in total skills of communication acquired by social inspectors of both groups. While only $5.2 \%$ of the skills were build in the $\mathrm{C}$ group, the experimental group, in contrast, is marked with a total $93.3 \%$ skill upgrade growth.

Deviations between the final assessment regarding behavioural skills in the two groups proved the methodology efficacy to develop social worker communication culture in the post-graduate training. Statistically significant differences between the groups was found in the cluster of skills such as involving a collocutor in common action, using non-verbal communication, acting tactfully, empathising and being eloquent.

The statistic difference between the other elements of the behavioural component, but for two skills, have a probability of 1.01 , i.e. $\mathrm{P}<0.01$. There is an apparent difference between the initial and final levels of social inspectors' skills of communication, proved additionally by expert assessment; therefore we can logically conclude that research objective was achieved.

As we see from Table 2, due to formative stage of the research $39.0 \%$ of social workers in the experimental group upgraded their communicative culture to the high level, while the number of those with medium and low levels of communicative culture decreased. Moreover, by way of comparison we found evident statistic differences in all the component of communicative culture. They most significant difference marked behavioural component test parameters, which provides justification of our hypothesis.

\section{Conclusions}

The research findings prove that the suggested methodology confers the high level of postqualifying training of social inspectors to communicate effectively. The results of the research ascertain the choice of the instructional content, organisation forms and methods of post-graduate training based on the substantiated pedagogical conditions. This research provides implications for post-qualifying and skill-upgrading training programmes for social workers in Ukraine. The foremost change which will definitely involve the reconsidering of the whole vocational training system is an integrated course, ensuring the development of communicative culture structural components in their integrity but not as independent skills or values, which should be reflected in both the teaching materials and organisational forms. Such a training will foster social worker's reflection on every component and element of own communicative culture. Furthermore, the module approach to instructional material organisation can provide reflect the specific features of social worker professional communication and be modified according to the current needs. Finally following the principles of social psychological training in the training program facilitates communication and interaction skills and provides opportunities to adhere to ethical standards. However, the results of the study should be treated with certain caution as a sample is limited to Dnipropetrovsk and Zaporizhzhya regions of Ukraine, while other areas might have different needs and thus require a somewhat different training course. We advocate further research in all the regions of Ukraine to solve the problem of quality education for social work and, therefore, building the Ukrainian society to world standards of social welfare. 


\section{References}

[1] Standards of Proficiency - Social workers in England, Health and Care Professions Council (HCPC), London, 2012. Retrieved on 24 December 2015 from www.hcpc-uk.org

[2] Core Competencies and Practice Behaviors, CSWE Accreditation Information, Modified on 9 April 2015, Retrieved on 29 December 2015 from https://www.uaf.edu/socwork/csweaccreditation-inform/

[3] S.P. Morreale, M.M.Osborn and J.C. Pearson, Why Communication is Important: a Rationale for the Centrality of the Study of Communication, Journal of the Association for Communication Administration, 29(2000), 1-25.

[4] G. Miasoid. Strukturna model' komunikatyvnoi kul'tury sotsial'noho pratsivnyka [The Structural Model of the Social Worker Communication Culture], Aktual'ni problemy teorii $i$ praktyky sotsial'noi roboty [Relevant Issues of Social Work], V.Vasyl'ev (ed.), Dnipropetrovsk National University Press, Dnipropetrovsk, Ukraine, 2003, pp. 20-27. (In Ukrainian)

[5] Educational Policy and Accreditation Standards (2008), the Council on Social Work Education, Inc. Revised March 27, 2010 / Updated August 2012. Retrieved on December 30, 2015 from http://www.cswe.org/Accreditation/2008EPASDescription.aspx

[6] AASW. AASW code of ethics. Kingston: Australian Association of Social Workers, 1999.

[7] CASW Canadian Association of Social Workers. Code of Ethics, Ottawa, Ontario, Canada, 2005.

[8] NASW. Code of Ethics. Washington: National Association of Social Workers, 1999.

[9] G. Miasoid, Pedahohichni umovy rozvytku komunikatyvnoi kul'tury sotsial'nykh inspektoriv u protsesi pidvyschennia kvalifikatsii [Pedagogical conditions of development of communicative culture of social inspectors in skill improvement process], Dis ... candidate. ped. Sciences: 13.00.04 Theory and methodology of vocational training, Ternopil National Pedagogical University named after Volodymyr Ghatyuk, Ternopil, 2005, 317p. (In Ukrainian)

[10] A Skilled Workforce for Strong, Sustainable and Balanced Growth, A G20 Training Strategy, International Labour Office, Geneva, November 2010. Retrieved on 29 December 2015 from http://www.oecd.org/g20/topics/employment-and-social-policy/G20-Skills-Strategy.pdf

[11] Assessment of Student Learning Outcomes for BSW. Modified on 9 April 2015. Retrieved on 30 December, 2015 from

https://www.uaf.edu/socwork/cswe-accreditation-

inform/ASSESSMENTOFSTUDENTLEARNINGOUTCOMESFORMBSW.docx 